\title{
A Study of Urea-synthesizing Enzymes in Prenatal and Postnatal Human Liver
}

\author{
KAZUHIKO OYANAGI, M.D., KIMIE NAKAMURA, M.D., HIDEAKI SOGAWA, M.D., \\ HIDEAKI TSUKAZAKI, M.D., RYOJI MINAMI, M.D., AND TOORU NAKAO, M.D.
}

Department of Pediatrics, Sapporo Medical College, Sapporo, Japan

\section{Summary}

The urea-synthesizing enzymes of human liver tissues, namely, carbamylphosphate synthetase (CPS, EC 2.7.2.2), ornithine transcarbamylase (OTC, EC 2.1.3.3), arginine synthetase system, argininosuccinase (ASase, EC 4.3.2.1), and arginase (EC 3.5.3.1) were measured between pre- and postnatal periods.

Specimens from 67 autopsied human livers obtained from fetuses, premature infants, newborn infants, infants, children, and adults were examined.

The mean activities of the enzymes showed an increased pattern for OTC and arginase at fetal life, whereas those of CPS, arginine synthetase system, and ASase of fetal livers showed no significant difference in each stage. Except for arginase, the other four enzyme activities were higher in the postnatal period than those in the fetal life. Arginase activities indicated maximal increase at a gestational age between 28 and 31 weeks and decreased in the postnatal life.

\section{Speculation}

The present study demonstrated that each of urea-synthesizing enzymes during fetal life developed independently. All five enzyme activities were present in $30 \%$ or more of the children even at a gestational age of between 12 and 19 weeks, and the enzyme activities of arginase increased with gestational age until birth. From the results, it may be possible to speculate that urea synthesis is always increasing during fetal periods.

Enzyme activities of the urea synthesizing have been studied by several investigators, mostly with materials of experimental animals $(1,4,10,12,13)$. Experiments by Kennan and Cohen (4) and Räihä and Kretchmer (8) have shown that the urea-synthesizing enzyme activities in rat liver are not active before birth, but that soon afterwards the enzyme activities increase to adult levels. Only a few studies of the urea-synthesizing enzymes during fetal development have been made $(3,5,9)$; individual enzyme activities can be detected much earlier in fetal life and increase roughly with gestational age until birth.

Systemic studies of the urea cycle enzyme in liver during human development have not been done.

The purpose of this study is to measure these enzyme activities in the specimens of 67 autopsied human livers obtained from fetuses, premature infants, newborn infants, infants, children, and adults.

\section{MATERIALS AND METHODS}

Thirty-six human fetal livers were obtained from legal abortions. The gestational age of the fetuses ranged between 12 and 31 weeks. Thirty-one livers of postnatal subjects were obtained by autopsy from patients who had neither evidence of liver disease nor metabolic disorder. Seven premature infants, weighing 1500 to $2200 \mathrm{~g}$ at birth, were diagnosed as having respiratory distress syndrome or pulmonary hemorrhage. These premature infants never survived longer than $48 \mathrm{hr}$, and they had no symptoms of hyperammonemia. All liver materials were frozen under $-80^{\circ} \mathrm{C}$ within $4 \mathrm{hr}$ after autopsy until the enzyme could be analyzed. The activities of carbamylphosphate synthetase (CPS), arginine synthetase system, and argininosuccinase (ASase) in liver tissues were assayed in triplicate by the method of Brown and Cohen $(1,2,7)$. The activities of ornithine transcarbamylase (OTC) and arginase were assayed in triplicate by the method of Schimke et al. (12). Enzyme activity was expressed as $\mu$ moles products per hr per mg protein. The enzyme activities were stable with storage at $-80^{\circ} \mathrm{C}$ for 6 months and did not change during $4 \mathrm{hr}$ after abortion or autopsy. The protein content in liver tissues was estimated by the method of Lowry et al. (6).

\section{RESULTS}

\section{PROTEIN CONTENT OF THE HUMAN LIVER TISSUES}

The results obtained are shown in Figure 1; there was no difference between protein contents in liver from fetuses and postnatal subjects.

\section{THE ACTIVITIES OF UREA-SYNTHESIZING ENZYMES IN LIVER} TISSUES

The results obtained are shown in Table 1 and Figures 2 to 6 . The statistical analysis of the results by Student's $t$ test is given in Table 2.

The mean activities of urea-synthesizing enzymes showed an increase pattern for OTC and arginase at fetal life, whereas those of CPS, arginine synthetase system, and ASase of fetal livers showed no significant difference in each stage. Except arginase, the other 4 enzyme activities were higher in the postnatal period than those in the fetal life. Arginase activities indicated maximal increase at a gestational age of between 28 and 31 weeks and decreased in the postnatal life. The enzyme activities of arginine synthetase system of premature infants showed the lowest value.

The degree of urea-synthesizing enzyme activities in each stage was expressed as a percentage of the value measured in childhood (Fig. 7). All 5 enzyme activities were present in $30 \%$ or more of the children, even at a gestational age of between 12 and 19 weeks.

\section{DISCUSSION}

A number of studies on urea-synthesizing enzyme in experimental animals have been reported in recent years $(1,4,10,11$, 14). In experimental animals, the developmental pattern of ureasynthesizing enzyme activities was different from those of human embryo. Kennan and Cohen (4) and Räihä and Kretchmer (8) reported that the urea-synthesizing enzyme activities in rat liver were not active during fetal periods, but that soon after birth the enzyme activities increased to adult levels. 
In 1961, Kennan and Cohen (5) reported that urea-synthesizing enzyme activities with the material of human embryo were detectable at 3 to 4 months gestation. Subsequently, Colombo and Richterich (3) reported that urea-synthesizing enzymes in human liver were detected from the 50th day of pregnancy, and all enzymes showed two peaks during the 50th and 110 th days of gestation except for OTC activity. They speculated that higher activities (two peaks) might be due to an increase urea synthesis during those periods. Räihä and Suihkonen (9) reported that ureasynthesizing enzymes of human liver increased roughly with gestational age until birth, and the enzyme activities in the fetal and newborn livers were slightly lower than those found in the adult liver.

The results obtained from present study are in agreement with those mentioned above $(3,9)$ that the activities of urea-synthesizing enzyme except arginase were higher in the postnatal than in the fetal life. The present study demonstrated that each of ureasynthesizing enzymes during fetal life developed independently. No significant difference was observed in enzyme activities of
CPS, arginine synthetase system, and ASase during fetal periods, and these enzyme activities were lower than those of postnatal periods. These results are a little different from those of previous studies, but it is difficult to compare the data reported by previous investigators and by present authors because most of the fetal materials used by earlier investigators were under 20 weeks of gestation.

The most characteristic findings observed in this study are as follows: the enzyme activities of OTC increased with gestational age and continued until childhood, the enzyme activities of arginase increased with gestational age until birth and after that decreased towards infant age.

From the results of present study, it may be possible to speculate that urea synthesis is always increasing during fetal periods.

Because the enzyme activities of arginine synthetase system showed the lowest value among urea-synthesizing enzymes, this enzyme should be rate limiting.

The activities of arginine synthetase system in liver specimens of premature infants were very low, but etiology is obscure.

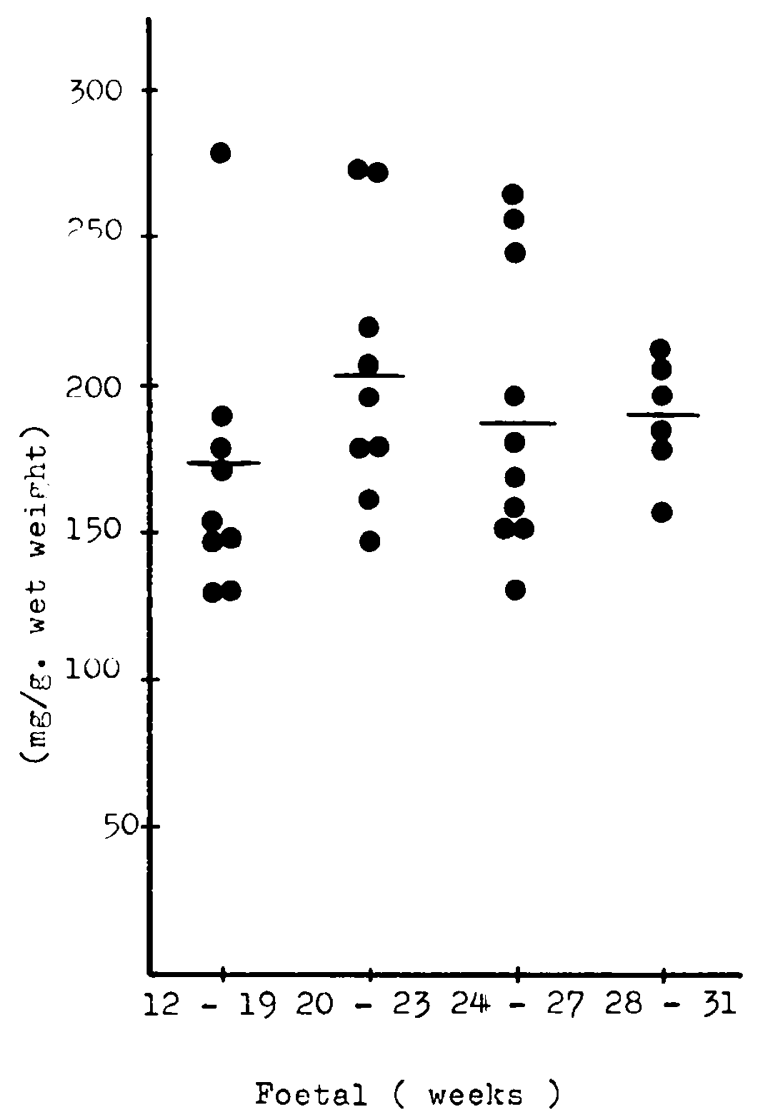

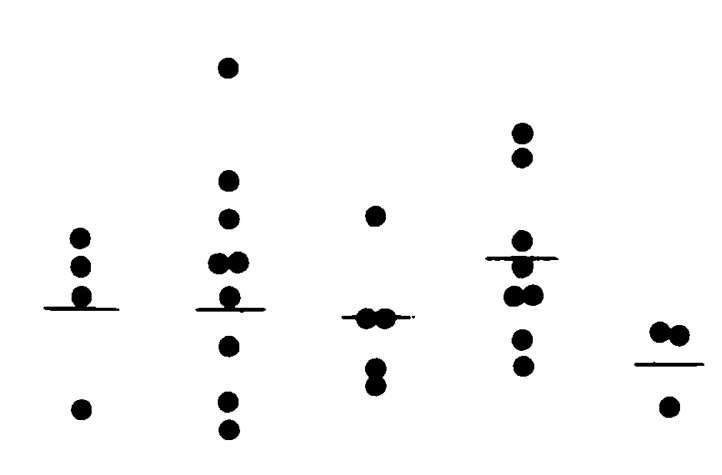

Dremature newborn $1-121-9$ adult
infant

Postnatal

Fig. 1.

Table 1. Summary of specific activities of urea-synthesizing enzymes ( $\mu$ moles product per mg protein per hr)

\begin{tabular}{|c|c|c|c|c|c|c|c|c|c|c|}
\hline \multirow[b]{2}{*}{ Age } & \multicolumn{2}{|l|}{ CPS } & \multicolumn{2}{|l|}{ OCT } & \multicolumn{2}{|l|}{ ASS $^{\prime}$} & \multicolumn{2}{|l|}{ ASase } & \multicolumn{2}{|l|}{ Arg } \\
\hline & Mean \pm S.D. & $N$ & Mean \pm S.D. & $N$ & Mean \pm S.D. & $N$ & Mean \pm S.D. & $N$ & Mean \pm S.D. & $N$ \\
\hline $12-19 w k$ & $0.89 \pm 0.32$ & 9 & $10.68 \pm 3.9$ & 9 & $0.28 \pm 0.18$ & 9 & $2.33 \pm 1.42$ & 10 & $47.18 \pm 29.31$ & 10 \\
\hline $20-23$ wk & $0.89 \pm 0.63$ & 10 & $13.60 \pm 4.95$ & 8 & $0.32 \pm 0.19$ & 9 & $2.44 \pm 1.25$ & 10 & $68.03 \pm 35.11$ & 10 \\
\hline 24-27 wk & $1.26 \pm 0.50$ & 8 & $15.21 \pm 5.9$ & 10 & $0.19 \pm 0.07$ & 10 & $2.68 \pm 1.02$ & 10 & $89.51 \pm 22.65$ & 9 \\
\hline $28-31$ wk & $0.95 \pm 0.4 !$ & 6 & $15.69 \pm 2.32$ & 6 & $0.22 \pm 0.08$ & 6 & $3.09 \pm 1.33$ & 6 & $110.46 \pm 29.96$ & 6 \\
\hline Premature & $1.83 \pm 1.53$ & 6 & $18.79 \pm 3.20$ & 7 & $0.08 \pm 0.04$ & 4 & $3.71 \pm 2.86$ & 7 & $85.35 \pm 57.37$ & 7 \\
\hline Newborn & $2.26 \pm 0.89$ & 8 & $23.65 \pm 9.86$ & 8 & $0.33 \pm 0.16$ & 8 & $3.46 \pm 2.92$ & 8 & $47.32 \pm 23.16$ & 8 \\
\hline $1-12$ months & $1.93 \pm 0.39$ & 5 & $30.46 \pm 6.58$ & 5 & $0.58 \pm 0.15$ & 5 & $4.41 \pm 1.79$ & 5 & $49.19 \pm 10.09$ & 4 \\
\hline 1-9 years & $1.59 \pm 1.48$ & 8 & $36.95 \pm 11.85$ & 8 & $0.55 \pm 0.29$ & 8 & $3.94 \pm 1.24$ & 8 & $80.33 \pm 35.57$ & 8 \\
\hline Adult & $1.15 \pm 0.19$ & 2 & $20.67 \pm 3.08$ & 3 & $0.54 \pm 0.31$ & 3 & $3.78 \pm 1.54$ & 3 & $87.37 \pm 44.35$ & 3 \\
\hline
\end{tabular}



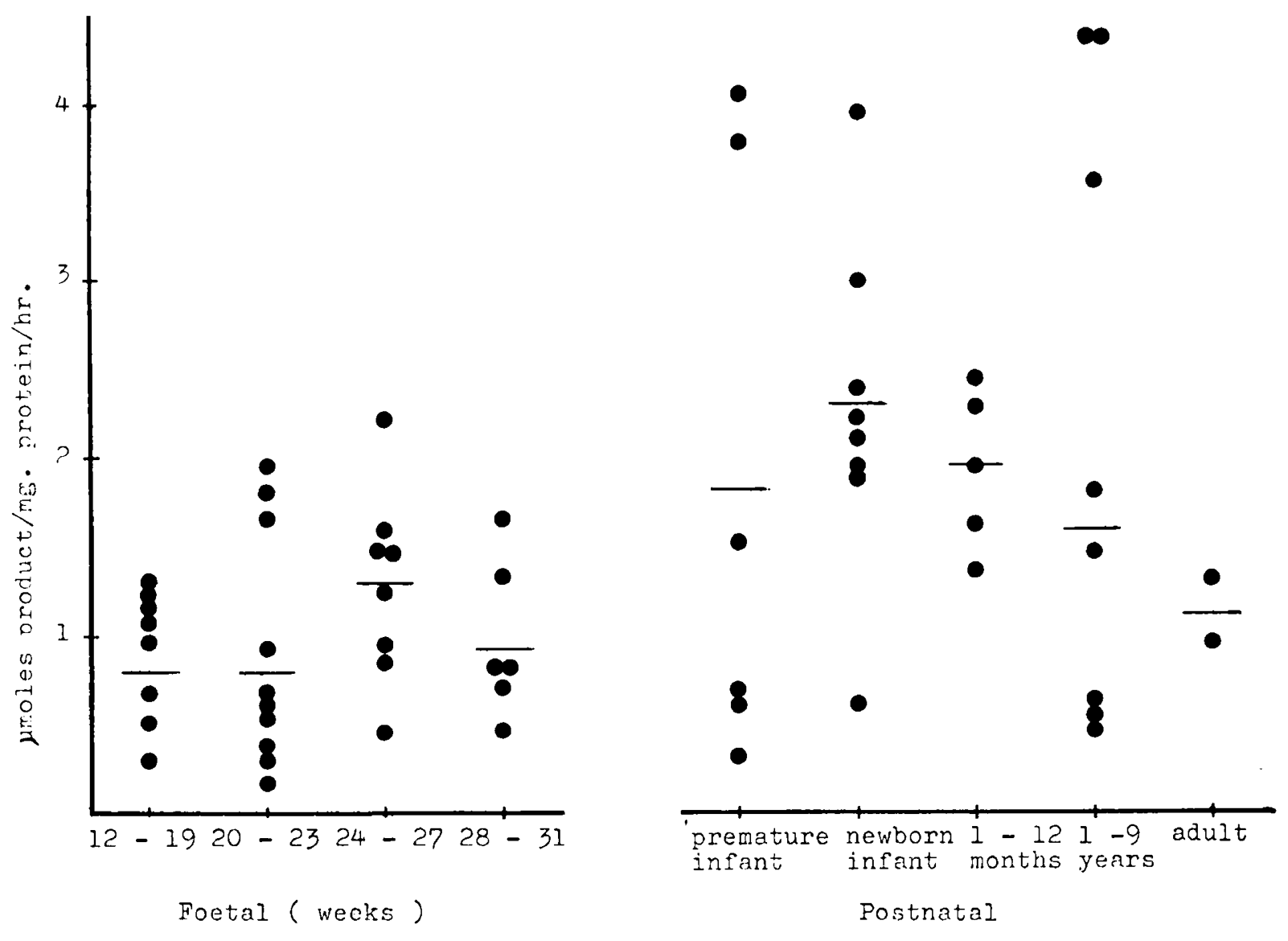

Fig. 2.
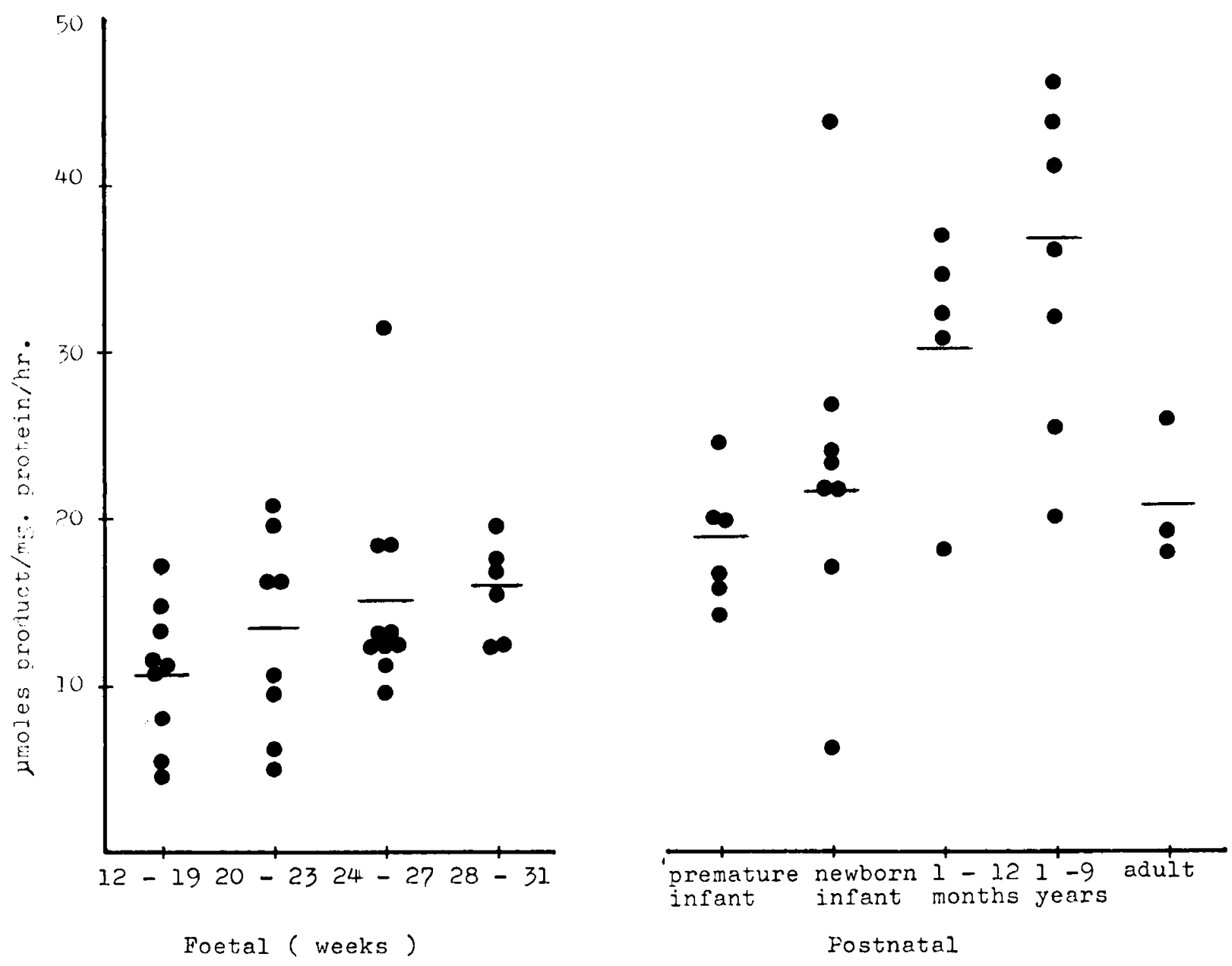

Fig. 3. 

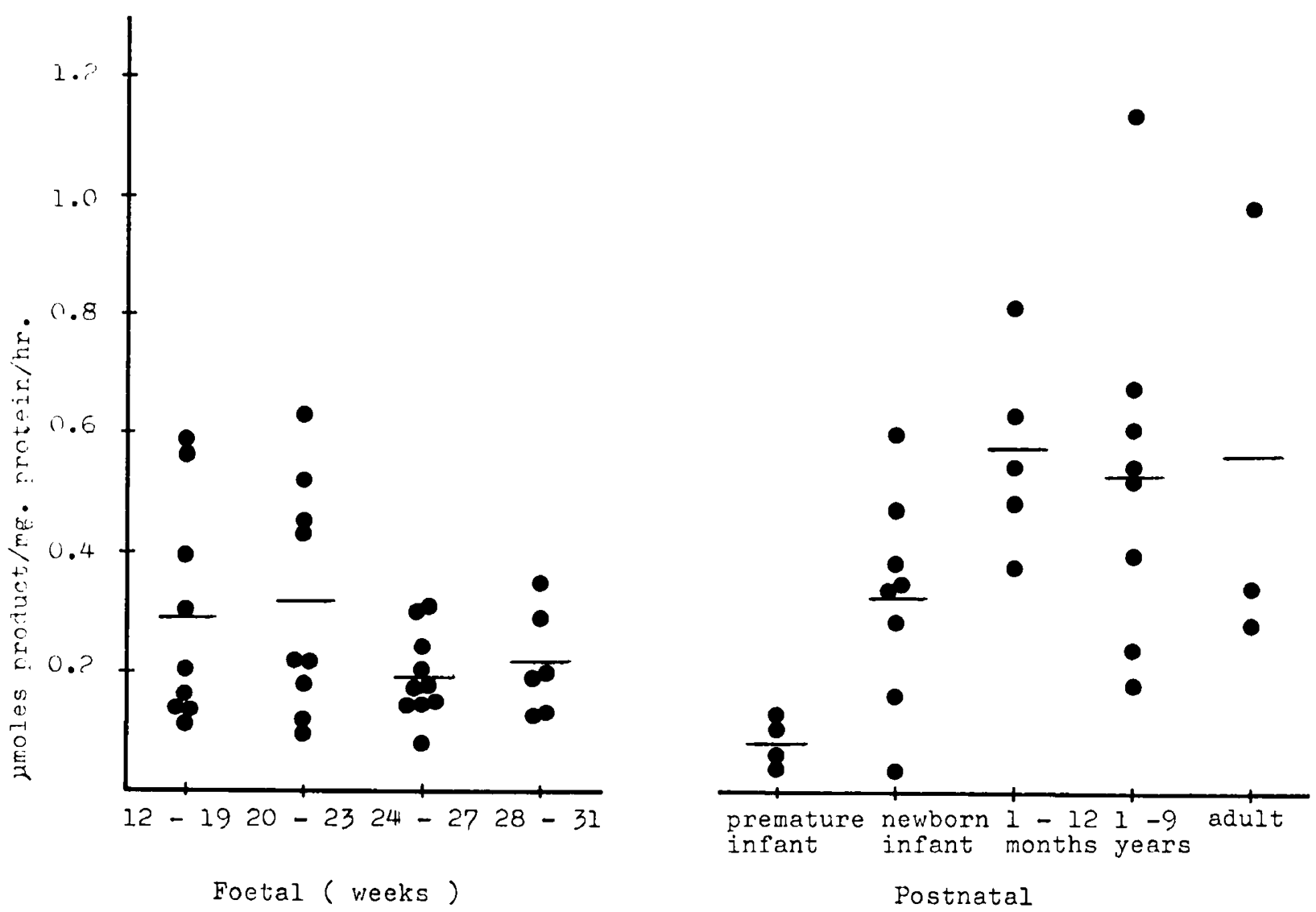

Fig. 4.
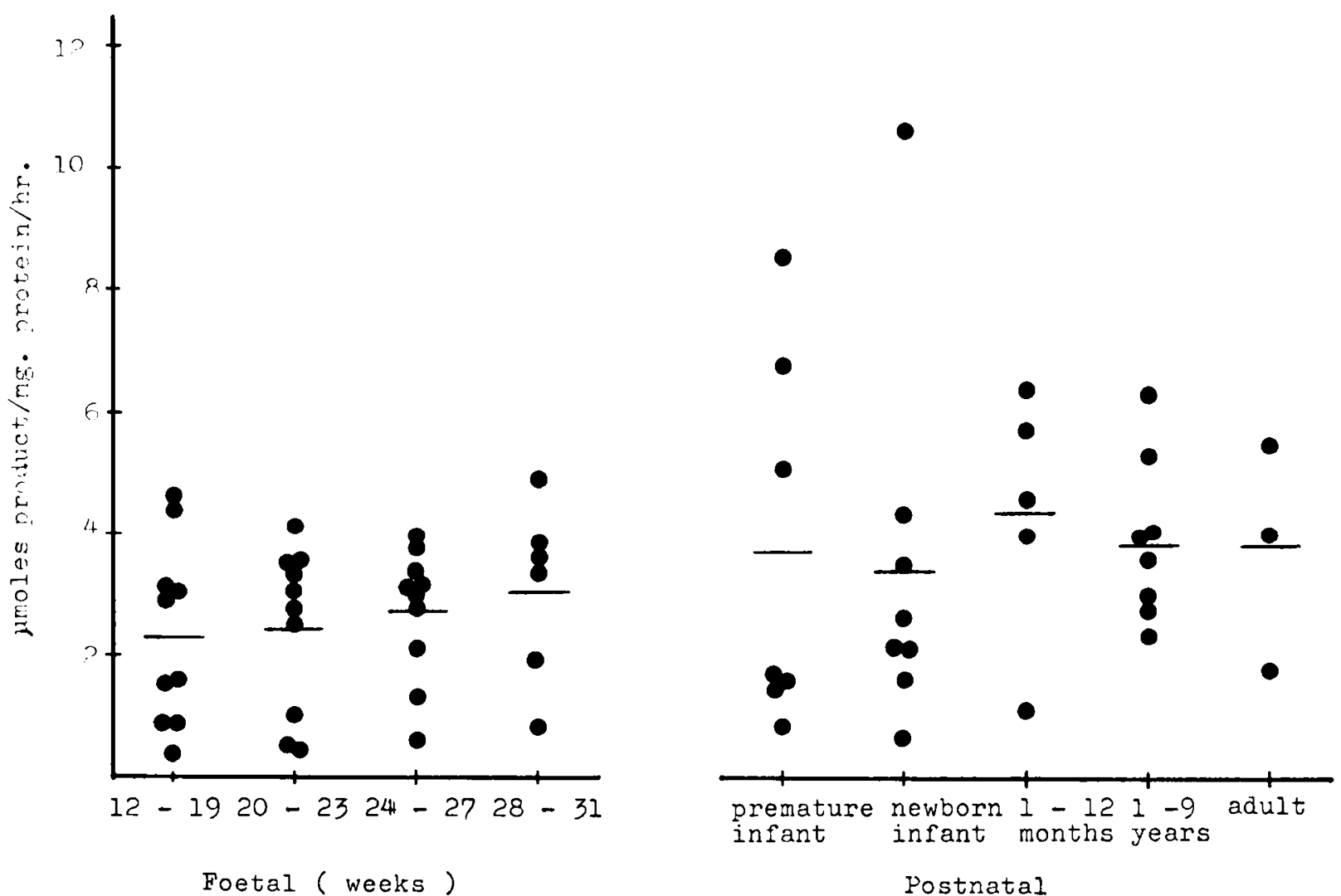

Fig. 5. 

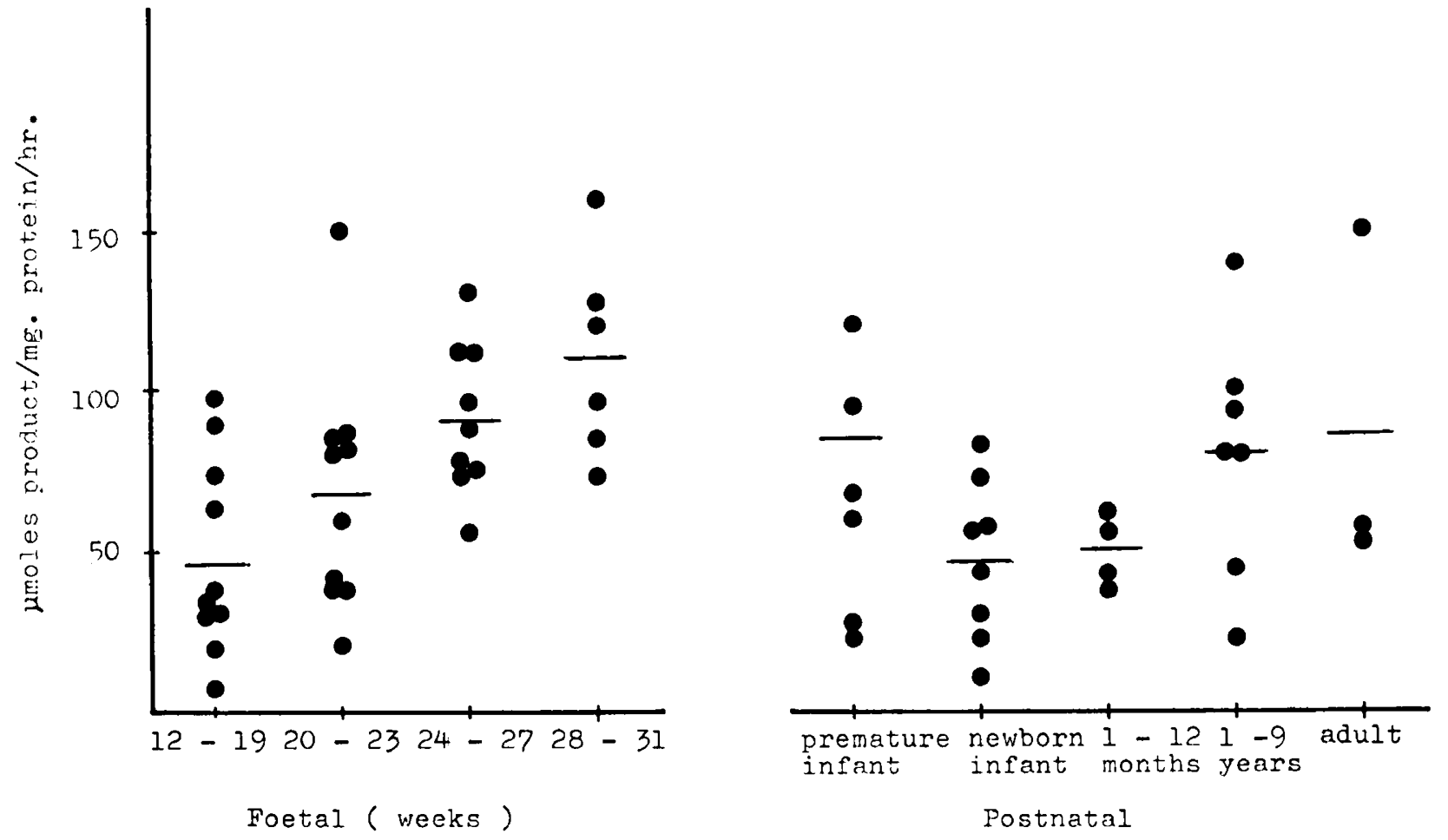

Fig. 6.

Table 2. Statistical analysis by Student's t-test

\begin{tabular}{|c|c|c|c|c|c|c|c|c|c|c|c|c|c|c|c|c|}
\hline & \multicolumn{8}{|c|}{ CPS } & \multicolumn{8}{|c|}{ OCT } \\
\hline & $20-23$ & 24-27 & $28-31$ & $\begin{array}{l}\text { Pre- } \\
\text { ma- } \\
\text { ture }\end{array}$ & $\begin{array}{l}\text { New- } \\
\text { born }\end{array}$ & $\begin{array}{c}1-12 \\
\mathrm{~m}\end{array}$ & $1-9 Y$ & adult & $20-23$ & 24-27 & $28-31$ & $\begin{array}{l}\text { Pre- } \\
\text { ma- } \\
\text { ture }\end{array}$ & $\begin{array}{l}\text { New- } \\
\text { born }\end{array}$ & $\begin{array}{c}1-12 \\
\mathrm{~m}\end{array}$ & $1-9 Y$ & adult \\
\hline $12-19 W$ & ND $^{\prime}$ & ND & ND & ND & $\cdots$ & $\ldots$ & ND & ND & ND & ND & $\cdot$ & $\cdots$ & $\ldots$ & $\cdots$ & $\ldots$ & ND \\
\hline $20-23$ & & ND & ND & ND & $\cdots$ & $\cdots$ & ND & ND & & ND & ND & $\cdot$ & . & $\cdots$ & $\cdots$ & ND \\
\hline 24-27 & & & ND & ND & ND &. & ND & ND & & & ND & ND & . & $\ldots$ & $\cdots$ & ND \\
\hline $28-31$ & & & & ND & $\cdots$ & $\cdots$ & ND & ND & & & & ND & ND & $\cdots$ & $\cdots$ & ND \\
\hline Premature & & & & & ND & ND & ND & ND & & & & & ND & $\cdots$ & $\cdots$ & ND \\
\hline Newborn & & & & & & ND & ND & ND & & & & & & ND & $\cdot$ & ND \\
\hline $1-12 m$ & & & & & & & ND & ND & & & & & & & ND & ND \\
\hline \multirow[t]{3}{*}{$1-9 Y$} & & & & & & & & ND & & & & & & & & ND \\
\hline & \multicolumn{8}{|c|}{$\mathrm{ASS}^{2}$} & \multicolumn{8}{|c|}{ Arg } \\
\hline & $20-23$ & 24-27 & $28-31$ & $\begin{array}{l}\text { Pre- } \\
\text { ma- } \\
\text { ture }\end{array}$ & $\begin{array}{l}\text { New- } \\
\text { born }\end{array}$ & $\begin{array}{r}1-12 \\
\mathrm{~m}\end{array}$ & $1-9 Y$ & adult & $20-23$ & $24-27$ & $28-31$ & $\begin{array}{l}\text { Pre- } \\
\text { ma- } \\
\text { ture }\end{array}$ & $\begin{array}{l}\text { New- } \\
\text { born }\end{array}$ & $\begin{array}{r}1-12 \\
\mathrm{~m}\end{array}$ & $1-9 Y$ & adult \\
\hline $12-19 \mathrm{~W}$ & ND & ND & ND & ND & ND & $\ldots$ & ND & ND & ND & $\ldots$ & $\ldots$ & ND & ND & ND & ND & $\ldots$ \\
\hline $20-23$ & & $\mathrm{ND}$ & ND & $\cdot$ &. &. & . & ND & & ND & ND & ND & ND & ND & ND & ND \\
\hline $24-27$ & & & ND & $\cdot$ & $\cdot$ & $\ldots$ & $\cdots$ &. & & & ND & ND & $\ldots$ & $\ldots$ & ND & ND \\
\hline $28-31$ & & & & ND & $\cdot$ & . & $\ldots$ & $\cdot$ & & & & ND & $\ldots$ & $\ldots$ & ND & ND \\
\hline Premature & & & & & $\cdot$ & $\cdots$ & . & ND & & & & & ND & ND & ND & ND \\
\hline Newborn & & & & & & $\cdot$ & ND & ND & & & & & & ND & ND & ND \\
\hline $1-12 m$ & & & & & & & ND & ND & & & & & & & ND & ND \\
\hline $1-9 Y$ & & & & & & & & ND & & & & & & & & ND \\
\hline
\end{tabular}

${ }^{1} \mathrm{ND}$, no significant difference; $\cdot, P<0.05 ; \cdots, P<0.01$.

${ }^{2}$ ASS, Arginine synthetase system, Arg, arginase. 

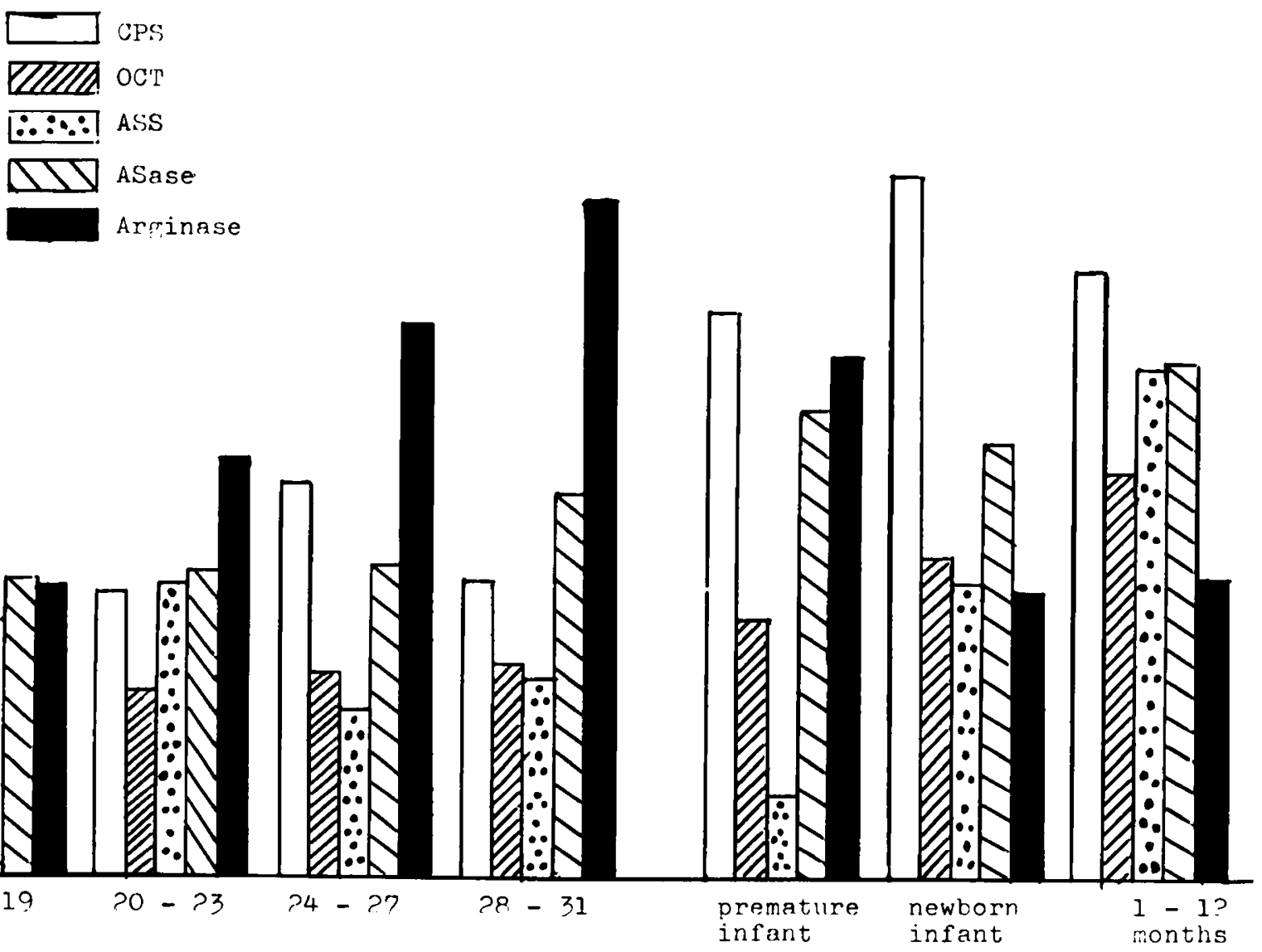

Foetal (weeks)

Postratal

Fig. 7.

\section{REFERENCES AND NOTES}

1. Brown, G. W., and Cohen, P. P.: Comparative biochemistry of urea cycle enzymes in liver. J. Biol. Chem.. 234: 1796 (1959).

2. Burnett, G. H., and Cohen, P. P.: Study of carbamyl phosphate ornithine transcarbamylase. J. Biol. Chem., 229: 337 (1957).

3. Colombo, J. P., and Richterich, R.: Urea cycle enzymes in the developing human fetus. Enzymol. Biol. Clin., 9: 68 (1968).

4. Kennan, A. L., and Cohen. P. P.: Biochemical studies of the developing mammalian fetus. I. Urea cycle enzymes. Dev. Biol., I: 511 (1959).

5. Kennan, A. L., and Cohen, P. P.: Ammonia detoxication in liver from humans. Proc. Soc. Exp. Biol. Med., 106: 170 (1961).

6. Lowry, O. H., Rosenbrough, N. J., Farr, A. L., and Randall, R. J. Protein measurement with the Folin phenol reagent. J. Biol. Chem., 193: 265 (1951).

7. Masshall, M., and Cohen, P. P.: Omithine transcarbamylase from Streptococcus faecalis and bovine liver. J. Biol. Chem., 247: 1641 (1972).
8. Räihä, N. C. R., and Kretchmer, N.: Urea biosynthesis during development of the mammal. J. Pediatr., 67: 950 (1965).

9. Räihä, N. C. R., and Suihkonen, J.: Development of urea-synthesis enzymes in human liver. Acta Paediatr. Scand., 57: 121 (1968).

10. Ratner, S.: Coordinated changes in enzymes of the ornithine cycle. Adv. Enzymol., 39: 66 (1973).

11. Schimke, R. T.: Adaptive characteristics of urea cycle enzyme in the rat. J. Biol. Chem., 237: 459 (1962).

12. Schimke, R. T.: Studies on factors affecting the levels of urea cycle enzymes in rat liver. J. Biol. Chem., 238: 1012 (1963)

13. Schimke, R. T.: The importance of both synthesis and degradation in the control of arginase levels in rat liver. J. Biol. Chem., 239: 3808 (1964).

14. Informed consent was obtained for all subjects in this study.

15. Received for publication November $21,1978$.

16. Accepted for publication April 10, 1979. 